\title{
EFFECT OF LIQUID FEED ADDITIVE TEMPERATURE ON DOSING ACCURACY IN FEEDING STATION FOR DAIRY CATTLE
}

\author{
Jaroslaw Chlebowski, Marek Gaworski, Tomasz Nowakowski, Aleksandra Szczesniak \\ Warsaw University of Life Sciences, Poland \\ jaroslaw_chlebowski@sggw.pl, marek_gaworski@sggw.pl, tomasz_nowakowski@sggw.pl
}

\begin{abstract}
Some needs to increase the efficiency of dairy production affect improvement of nutrition technology. In addition to constantly expanding the offer of liquid feed additives that complement nutrient deficiencies in the diet, manufacturers are introducing more and more innovative devices for dispensing them. The changing ambient temperature at which liquid feed additives are fed may affect their dispensing quality. Therefore the aim of this study was to determine the temperature effect of various liquid feed additives on the accuracy of their dosing in a feeding station for dairy cattle. To reach the aim of the study the test stand was built basing on the feeding station for dairy cattle. The test stand was equipped with a DeLaval membrane feeder GD 500. The operation of the feeder was based on the principle of the diaphragm pump. To determine the accuracy of dosing by the fodder membrane feeder the dosing accuracy indicator was determined. Three different liquid feed additives were used to check the inaccuracy of dosing. The tests were carried out for four different temperatures of feed additives. The highest mean value of dosing inaccuracy (about $10 \%$ ) was achieved with Glycol Plus at the temperature of $20^{\circ} \mathrm{C}$. The results of the experiment showed the statistically significant effect of temperature and feed additive type on the dosing accuracy. As a result of the investigations it was found that in addition to the density of preparations changes in the accuracy of their dosage may be influenced by their other physical properties.
\end{abstract}

Keywords: liquid feed additives,dosing accuracy, membrane feeder.

\section{Introduction}

Dairy cattle feeding is the key element and at the same time a complex process within the dairy production system including technical aspects of dairy production development [1]. Quality of each diet component, as well as appropriate feed balancing show effect on the production capacity, milk composition, animal health [2] and their fertility [3]. In order to increase the milk productivity and animal health, liquid feed additives (energy additives) and feed concentrates are served to cows [4-7]. The liquid additives and feed concentrates can be delivered together with fodder or as an independent component. Doses of delivered concentrates and additives can affect milk yield per cow [8-9]. Contemporary approach to feeding of high productivity cows should include feed additives, which show positive effect on rumen metabolism and improvement of energetic-protein balance of the feeding dose $[4 ; 10]$. Popular and very often used liquid feed additives in the period of cow drying and delivery are propylene glycol and glycerol $[6 ; 11]$. These additives are the source of increased nutrient availability and improved concentration of glucose and insulin in blood serum and prevent ketosis [1213]. However, the delivery of liquid feed additives to animals in unsuitable quantities may have a negative impact on dry matter intake and milk yield [11].

With the help of the automatic feeding system it is easy to form an accurate dose of feed additives, as well as plan time and dosing procedure [14]. However, some liquid feed additives (propylene glycol and glycerol) because of their physical properties can be a source of problems at the stage of feeding. The liquid feed additives consist of various supportive components, vitamins and minerals. Moreover, a change in the temperature inside a barn within the year and even during the day can bring changes in temperature of dosed substances. Increase in temperature of liquid substances affects a decrease in their density and absolute viscosity [15]. Such changes in physical properties and various compositions of dosed substances can cause differences in working accuracy of the dosing equipment.

At the current time, the tasks on dosing of liquid feed additives for cattle are fulfilled by membrane feeders installed in feeding stations. In some cases the feeders can be considered among the farmers as not comfortable solutions in the field of accuracy of dosed different liquid feed additives at their various temperatures.

Such problem was the inspiration to carry out some investigation concerning the feeder and its accuracy of liquid additive dosing. No available test results for dosing of liquid additives at different ambient temperatures were found in the available literature. At the same time, farmers - according to 
their own observations - raise the problem with the precision of dosing additives at changing temperatures in the barn.

The aim of this study was to determine the temperature effect of various liquid feed additives on the accuracy of their dosing in the feeding station for dairy cattle.

\section{Materials and methods}

The investigations were carried out in the Departmentof Biosystems Engineering, Warsaw University of Life Sciences - SGGW in Warsaw. To reach the aim of the study, the test stand was built basing on the feeding station for dairy cattle. The test stand was equipped with a DeLaval membrane feeder GD 500 characterized by a maximum flow of $51 \cdot \mathrm{h}^{-1}$, maximum pressure of 7 bar and the power demand of $37 \mathrm{~W}$. The operation of the feeder was based on the principle of the diaphragm pump.The feeder was cooperated with DeLaval feeding station operated by processor with Alpro software. To provide proper work conditions of the feeder, it was installed according to the producer of service manual. The set of dosing pipes was placed in a way to facilitate free taking of liquid. The feeder capacity was adjusted to maximum value (overflow valve in the feeder was closed). Before tests all valves, seals, bolted joints and filter impurities state were checked. The research was done for three various liquid feed additives. There were the following substances (including research symbols G): Propylene glycol $99 \%$ - G1 Glycol plus - G2 and Vittra Glycerin 80 - G3. The feed additives are characterized in Table 1. As there was no information about properties of the investigated feed additives in various temperatures, therefore densities of the feed additives for four following temperatures were examined: $\mathrm{T} 1-5^{\circ} \mathrm{C} \mathrm{T} 2-10{ }^{\circ} \mathrm{C} \mathrm{T} 3-15^{\circ} \mathrm{C}$ and $\mathrm{T} 4-20^{\circ} \mathrm{C}$. The temperature range was taken on the basis of farmers' recommendations indicating a problem with dosing at a temperature of 5 degrees Celsius. Manufacturers of the tested liquid feed additives do not specify the temperature range of their dosing.The densities were found for each given above temperature of the feed additives using a measuring cylinder of $1 \mathrm{dm}^{3}$ capacity and $1 \mathrm{~cm}^{3}$ scale, as well as an electronic balance of $0.1 \mathrm{~g}$ measurement uncertainty. To determine the density of liquid feed additives, each preparation was managed to temperature of $5^{\circ} \mathrm{C}$ as a result of cooling in a cold room. The following (higher) temperatures were received by heating the preparations including outside temperature of a room, where the experiment was carried out (ambient temperature during the experiment amounted to $20 \pm 0.2^{\circ} \mathrm{C}$ ). The measurements were repeated ten times. To keep the adjusted temperature, the container with liquid feed additive was kept in an isolated container filled with cold elements. Temperature was monitored by a LB-522T thermometer (produced by LAB-EL company) with outside sensor. Uncertainty of temperature measurement amounted to $0.1{ }^{\circ} \mathrm{C}$. When temperature of the additives was changed during the experiment by $\pm 0.2^{\circ} \mathrm{C}$, then the additives were cooled or warmed again.

Table 1

Characteristics of the tested liquid feed additives

\begin{tabular}{|c|c|c|c|}
\hline Specification & Propylene glycol 99 \% G1 & Glycol plus G2 & Vittra Glycerin 80 G3 \\
Application & $\begin{array}{c}\text { Reduces the risk of ketosis, } \\
\text { reduces the effects of a } \\
\text { negative energy balance }\end{array}$ & $\begin{array}{c}\text { Energy additive in liquid } \\
\text { against ketosis }\end{array}$ & $\begin{array}{c}\text { Used as a source of } \\
\text { energy in ruminant feeds }\end{array}$ \\
\hline Composition & Propylene glycol crude ash & $\begin{array}{c}\text { Propylene glycol: } 50 \% \\
\text { glycerin: } 43 \% \text { niacin } \\
\text { methionine sodium propionate }\end{array}$ & $\begin{array}{c}\text { Glycerol: min } 80 \% \\
\text { crude ash methanol }\end{array}$ \\
\hline Density & $1.036 \mathrm{~g} \cdot \mathrm{cm}^{-3}$ & - & $1.261 \mathrm{~g} \cdot \mathrm{cm}^{-3}$ \\
\hline Viscosity & $56 \mathrm{cP}$ & - & - \\
\hline Daily dose & $150-350 \mathrm{ml} \cdot$ day $^{-1}$ & $150-350 \mathrm{ml} \cdot$ day $^{-1}$ & for $500 \mathrm{ml} \cdot \mathrm{day}^{-1}$ \\
\hline
\end{tabular}

The investigations on dosing accuracy of liquid feed additives included at the first step the weighing offeed additives amount dozed on a one-off basis by the feeder. At the second step the weighed amount was compared with the data indicated by the ALPRO system. All measurements were carried out for the fixed dosing capacity amounted to $0.3 \mathrm{~kg} \cdot \mathrm{min}^{-1}$. The measurements were repeated five times for each kind of feed additives and four various temperatures. To determine the dosing accuracy of liquid feed additives, the following coefficient of dosing accuracy was calculated: 


$$
w d=\frac{\left|x_{r}-x_{p}\right|}{x_{r}} \cdot 100 \%
$$

where $w d$-dosing accuracy, \%;

$x_{r}$ - indicated values in the ALPRO system, g;

$x_{p}$ - mass of weighed tested sample $\mathrm{g}$.

Results of the measurements and calculations were used to carry out the statistical analysis using Statistica v.13.

Before the experiment the dosing system was calibrated. The calibration included measurement of the mass of liquid feed additive samples. Five samples were collected and average values for these samples were introduced (written) to the feeding station management system. The system was calibrated for each temperature of liquid feed additives included in the experiment. The calibrating samples were weighed using an electronic analytical balance with accuracy of $0.1 \mathrm{~g}$. The average values of sample mass $\left(m_{\text {kav }}\right)$ obtained during the calibration were entered into the feed station control system as integers (Table 2).

Table 2

Values of mass $\left(m_{k a v}\right)$ obtained during the calibrationentered into the feed station control system for 3 types of feed additives (G1 G2 G3) and for 4 their temperatures (T1 T2 T3 T4)

\begin{tabular}{|c|c|c|c|c|}
\hline \multirow{2}{*}{$\begin{array}{c}\text { Type of feed } \\
\text { additive }\end{array}$} & \multicolumn{4}{|c|}{$\boldsymbol{m}_{\text {kav }}, \mathbf{g}$} \\
\cline { 2 - 5 } & $\mathrm{T} 1-5^{\circ} \mathrm{C}$ & $\mathrm{T} 2-10^{\circ} \mathrm{C}$ & $\mathrm{T} 3-15^{\circ} \mathrm{C}$ & $\mathrm{T} 4-20^{\circ} \mathrm{C}$ \\
\hline $\mathrm{G} 1$ & 52.9 & 52.1 & 52.0 & 52.3 \\
\hline $\mathrm{G} 2$ & 47.2 & 47.0 & 47.3 & 46.8 \\
\hline $\mathrm{G} 3$ & 46.3 & 52.0 & 53.3 & 54.2 \\
\hline
\end{tabular}

\section{Results and discussion}

Including the change in the inner temperature in barns and needs for a more precise way to determine the physical properties of the feed additives, their density for different temperatures were investigated. Results of the density measurements were statistically analyzed. The average values of density concerning the samples of the investigated liquid feed additives were received, i.e. G1 G2 G3 at their different temperatures: $\mathrm{T} 1-5^{\circ} \mathrm{C} \mathrm{T} 2-10{ }^{\circ} \mathrm{C} \mathrm{T} 3-15^{\circ} \mathrm{C}$ and $\mathrm{T} 4-20^{\circ} \mathrm{C}$ (Table 3).

Table 3

\section{Average values $\left(\rho_{k a v}\right)$ standard deviation (SD) and $95 \%$ ranges for density of liquid feed additives for 3 levels of investigated substances (G1 G2 G3) and for 4 levels of their temperatures (T1 T2 T3 T4)}

\begin{tabular}{|c|c|c|c|c|c|}
\hline $\begin{array}{l}\text { Type of feed } \\
\text { additive }\end{array}$ & $\begin{array}{c}\text { Temperature } \\
{ }^{\circ} \mathrm{C}\end{array}$ & $\begin{array}{c}\rho_{k a v} \\
\mathbf{k g} \cdot \mathbf{m}^{-3}\end{array}$ & $\begin{array}{l}\text { SD } \rho_{k} \\
\mathbf{k g} \cdot \mathbf{m}^{-3}\end{array}$ & $\begin{array}{c}-95 \% \rho_{k} \\
\mathrm{~kg} \cdot \mathrm{m}^{-3}\end{array}$ & $\begin{array}{c}+95 \% \rho_{k} \\
\mathrm{~kg} \mathrm{~m}^{-3}\end{array}$ \\
\hline \multirow{4}{*}{ G1 } & 5 & 1035.2 & 0.25 & 1034.9 & 1035.6 \\
\hline & 10 & 1032.8 & 0.45 & 1032.4 & 1033.1 \\
\hline & 15 & 1030.3 & 0.40 & 1029.9 & 1030.7 \\
\hline & 20 & 1026.4 & 0.39 & 1026.0 & 1026.7 \\
\hline \multirow{4}{*}{ G2 } & 5 & 1125.5 & 0.61 & 1125.3 & 1125.8 \\
\hline & 10 & 1125.2 & 0.62 & 1124.9 & 1125.4 \\
\hline & 15 & 1124.9 & 0.40 & 1124.7 & 1125.1 \\
\hline & 20 & 1124.3 & 0.60 & 1124.1 & 1124.5 \\
\hline \multirow{4}{*}{ G3 } & 5 & 1251.2 & 0.42 & 1250.8 & 1251.5 \\
\hline & 10 & 1248.4 & 0.62 & 1248.0 & 1248.7 \\
\hline & 15 & 1246.9 & 0.40 & 1246.6 & 1247.3 \\
\hline & 20 & 1246.5 & 0.75 & 1246.1 & 1246.8 \\
\hline
\end{tabular}

Results of variance analysis showed significant statistical difference in the density concerning three investigated liquid feed additives G1 G2 G3 $\left(F_{v 1=2 v 2=105}=24.3215\right.$ at $\left.p<0.0001\right)$. Densities of these additives showed also statistically significant difference for their various temperatures during the experiment $\left(F_{v 1=3 v 2=105}=68\right.$ at $\left.\mathrm{p}<0.0001\right)$. 
Results of measurements on density of liquid feed additives in the following tests (10 tests for each temperature of the additive) did not show statistically significant difference $\left(F_{v 1}=9 v 2=105=0.1\right.$ at $p=0.92$ ). Within the main part of the experiment, to determine the effect of feed additive temperature on its dosing accuracy, the statistical analysis was conducted for various feed additives.

Considering the results of the statistical analysis, the temperature and type of the tested liquid feed additives showed statistically significant effect on their dosing accuracy in the feeding station for cattle (Table 4). Moreover, the two-stage statistical analysis showed that dosing accuracy of the liquid feed additives also depends on the interaction between the two considered factors, i.e. temperature and type of the liquid feed additives. But the effect of liquid feed additive on dosing accuracy showed various tendency for different kinds of the considered substances. An increasing tendency concerning the dosing accuracy for higher temperature of the additives was observed for additives G2 and G3 (Fig. 1, a, c). In this case, the more accurate dosing can result from decreased density of liquid feed additives associated with their higher temperature (Table 3 ).

Table 4

Variance analysis of the factors influencing the dosing accuracy of liquid feed additives

\begin{tabular}{|c|c|c|c|c|c|}
\hline Source & Sum of Squares & DF & Mean Square & $\boldsymbol{F}$-ratio & $\boldsymbol{P}$-Value \\
\hline Type of feed additives (G) & 230.429 & 2 & 115.214 & 427.252 & $<0.0001$ \\
\hline Temperature (T) & 15.941 & 3 & 5.314 & 19.705 & $<0.0001$ \\
\hline Interaction G×T & 244.533 & 6 & 40.755 & 151.135 & $<0.0001$ \\
\hline
\end{tabular}

Lower density of liquids affects the changes in their viscosity and in the result causes decrease in the resistance of flow by inner parts of the pump equipment [16]. The highest value of dosing accuracy was found for Vittra Glycerin 80 (G3) dozed at the temperature of $15^{\circ} \mathrm{C}$ and density of $1247 \mathrm{~kg} \cdot \mathrm{m}^{-3}$.

The highest dosing inaccuracy was found for $\mathrm{G} 2$ additive at temperature of $20^{\circ} \mathrm{C}$. In this case, it was observed that density of the mentioned additive was practically constant within the temperatures of $5-20{ }^{\circ} \mathrm{C}$ and amounted to about $1125 \mathrm{~kg} \cdot \mathrm{m}^{-3}$. Slightly lower density of this additive received at higher temperature, i.e. $20^{\circ} \mathrm{C}$, caused increase in the coefficient of dosing accuracy which amounted to $10 \%$.

a)

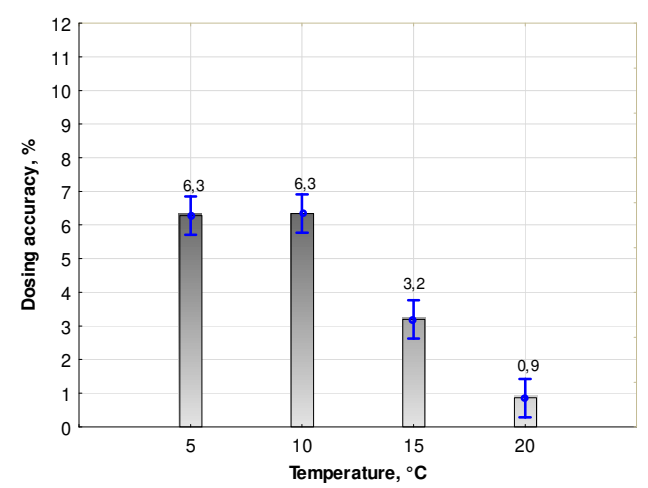

c) b)

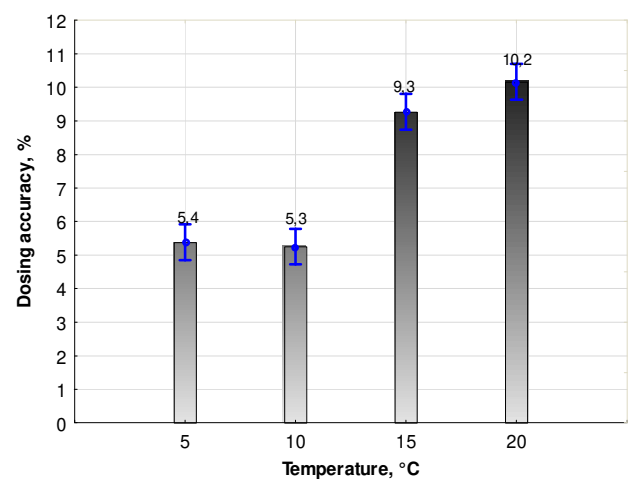

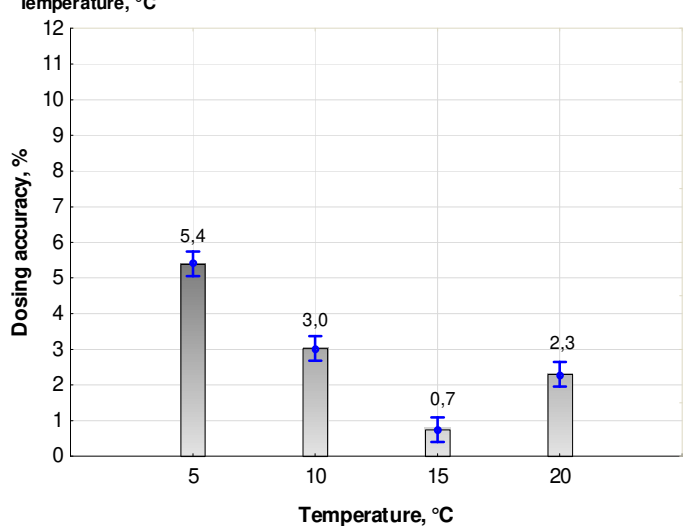

Fig. 1. Effect of the liquid feed additive temperature on the accuracy of dosing: a - Propylene glycol 99 \% (G1), b - Glycol plus (G2), c - Vittra Glycerin 80 (G3) 
Analyzing the results of the carried out investigations, it is possible to suppose that changes in accuracy of liquid feed additive dosing can result, besides their density, from other physical properties, like viscosity, thermal expansion and surface tension [17]. Significant effect on dosing accuracy of liquid nutritional supplements can be explained by the construction of the membrane feeder and its regulation of working capacity [14]. A different character of changes in dosing accuracy of Glycol plus should also be explained. The results of the test concerning this preparation showed the highest dosing inaccuracy at the highest temperature. To fully explain the effect of liquid nutritional supplement density on the precision of their dosing in feeding stations there can be suggested some additional investigations.

The problem of dosing accuracy can be considered in connection with such aspects like physiological parameters, feed intake, milk production and risk of ketosis of dairy cows, especially when propylene glycol is used [4]. There was recognized the effect of the method of delivery of propylene glycol on plasma metabolites of feed-restricted cattle [18]. The propylene glycol was also used in our experiment, so the metabolism of propylene glycol can be considered as one of the elements to assess the effect of dosing accuracy. It can be especially important, when long-term glycerol feeding is investigated and its effect on health and production of dairy cows [19]. This way the tested dosing accuracy of liquid nutritional preparations becomes a part of complex investigations on the efficiency of dairy cow feeding.

\section{Conclusions}

1. The results of the statistical analysis showed a significant effect of the temperature and type of the investigated liquid feed additives on their dosing accuracy in the feeding station for cows.

2. The carried out experiment showed that increased temperature of Propylene glycol $99 \%$ and VittraGlycerin 80 was associated with higher dosing inaccuracy by the membrane feeder. Lower dosing accuracy results from increased density of the feed additives. Only for Glycol plus it was possible to find that dosing accuracy showed the lowest value at the temperature of $20^{\circ} \mathrm{C}$ and at the same time dosing accuracy did not depend on the density of the considered substance.

3. Based on the results of the tests carried out, it can be suggested to store tanks with dosed liquid additives in insulated housings to eliminate changes in their dosing temperature during changing the barn conditions.

4. To better recognize some phenomena during liquid feed additive dosing in the feeding station with the membrane feeder there can be suggested some investigations including not only density, but also other physical properties of the preparations (viscosity, compressibility and surface tension), as well as the technical parameters of the feeder.

\section{References}

[1] Gaworski M., Leola A. Effect of technical and biological potential on dairy production development. Agronomy Research, 12, 2014, pp. 215-222.

[2] Kałuża H.,J akubiak K., Królicka M. Walczewska O. Wpływ system żywienianawydajnośćkrówmlecznych $\quad w$ wybranychstadachrasyholsztyńsko-fryzyjskiej (The effect of dairy cattle feeding system for milk production in selected herds of the holstein-frisian breed). Zeszyty Naukowe Uniwersytetu Przyrodniczo-Humanistycznego w Siedlcach. Seria Rolnictwo, 1, 2015, pp. 1-13. (In Polish).

[3] Kowalski Z.M., Kamiński J.Niektóre problemy żywienia krów wysokowydajnych.(Some problems of high productivity dairy cows feeding). PostępyNaukRolniczych, 4, 2000, pp. 77-98. (In Polish).

[4] Nielsen N.I., Ingvartsen K.L. Propylene glycol for dairy cows: a review of the metabolism of propylene glycol and its effects on physiological parameters feed intake milk production and risk of ketosis. Animal Feed Science and Technology, 115,2004, pp. 191-213.

[5] Ivemeyer S., Walkenhorst M., Holinger M., Maeschli A., Klocke P., Spengler Neff A., Staehli P., Krieger M.,Notz C. Changes in heard health fertility and production under roughage based feeding conditions with reduced concentrate input in Swiss organic dairy herds. Livestock Science, 168, 2014, pp. 159-167. 
[6] Pechová A., Pečínka P. Kudrnáčová J. Pavlata L. The comparison of propylene glycol and glycerol as feed additives in early lactation of high producing dairy cows. Journal of Animal and Feed Sciences, 23,2014, pp. 285-292.

[7] Soonberg M., Kass M., Kaart T., Lemingand R., Arney D.R. Additional concentrates do not affect feeding times of cows but social positions of cows do. Agronomy Research, 16,2018, pp. 18771884.

[8] Lawrence D.C., O’Donovan M.O., Boland T.M., Lewis E., Kennedy E. The effect of concentrate feeding amount and feeding strategy on milk production dry matter intake and energy partitioning of autumn-calving Holstein-Friesian cows. Journal of Dairy Science, 98, 2015, pp. 338-348.

[9] Purcell P.J., Law R.A., Gordon A.W.,McGettrick S.A., Ferris C.P. Effects of concentrate feeding method on the performance of dairy cows in early to mid-lactation. Journal of Dairy Science, 99,2016, pp. 2811-2824.

[10]Bilik K. Żywienie krów w okresie okołoporodowym (Feedingcows in the perinatal period). Hodowca Bydła, 11, 2015, pp. 10-18. (In Polish).

[11] Paiva P.G., Del Valle T.A., Jesus E.F., Bettero V.P., Almeida G.F,. Bueno I.C.S., Bradford B.J.,RennóF.P. Effects of crude glycerin on milk composition nutrient digestibility and ruminal fermentation of dairy cows fed corn silage-based diets. Animal Feed Science and Technology, 212, 2016, pp. 136-142.

[12]Bjerre-Harpøth V., Storm A., Eslamizad M., Kuhla B., Larsen M. Effect of propylene glycol on adipose tissue mobilization in postpartum over-conditioned Holstein cows. Journal of Dairy Science, 98, 2015, pp. 8581-8596.

[13] Piantoni P., Allen M.S. Evaluation of propylene glycol and glycerol infusions as treatments for ketosis in dairy cows. Journal of Dairy Science, 98,2015, pp. 5429-5439.

[14] Chlebowski J., Nowakowski T., Dąbrowska M., Sypula M., Koboska Ł. Effect of moisture content of granulated fodder on its dosing in feed station.Proceedings of 17th International Scientific Conference "Engineering for rural development", Jelgava, Latvia, May 23-25,2018, Vol. 17, pp. 77-82.

[15] Orzechowski Z., Prywer J. Rozpylanie cieczy(Liquid spraying). Wydawnictwo NaukowoTechniczne. Warszawa, 1991, 336 p. (In Polish).

[16] Stępniewski, M. Pompy(Pump). Wydawnictwo Naukowo-Techniczne. Warszawa, 1978, 560 p. (In Polish).

[17] Orzechowski Z.,Prywer J.,Zarzycki R. Fluid mechanics in engineering and environmental protection. WydawnictwoNaukowo-Techniczne. Warszawa, 2009, 623 p. (In Polish).

[18] Christensen J.O., Grummer R.R., Rasmussen F.E.,Bertics S.J. Effect of method of delivery of propylene glycol on plasma metabolites of feed-restricted cattle. Journal of Dairy Science, 80, 1997, pp. 563-568.

[19] Reichel P., Farkašová Z., Fabini M., Bobus A., Húska M., Seidel, H.,Kováč G. Effects of longterm glycerol feeding on health and production of dairy cows during peri-partal period. RevistaRomână de MedicinăVeterinară, 17(2), 2007, Suppl. Ia, 44. 